\title{
Kajian Bioprospeksi Daun Gatal (Laportea decumana), Kemaduh (Dendrocnide stimulans (L.f) Chew) dan Bedor (Girardinia palmata Gaud) di Desa Gubuk Klakah dan Desa Ngadas Kecamatan Poncokusumo Kabupaten Malang
}

\section{Bioprospection Study of Itchy Leaves (Laportea decumana), Kemaduh (Dendrocnide stimulans (L.f) Chew) dan Bedor (Girardinia palmata Gaud) in Gubuk Klakah and Ngadas Villages, Poncokusumo District, Malang Regency}

\author{
Ariski Vevi Liswandari ${ }^{1 *}$ Nour Athiroh Abdoes Sjakoer, ${ }^{2 * *}$ Ratna Djunuwati Lisminingsih ${ }^{3}$ \\ ${ }^{123}$ Program Studi Biologi, Jurusan Biologi, FMIPA, Universitas Islam Malang, Indonesia
}

\begin{abstract}
ABSTRAK
Daun gatal merupakan tumbuhan yang biasanya dijumpai oleh masyarakat, namun sebagian besar masyarakat tidak mengetahui manfaat dan kegunaannya sehingga daun gatal jarang digunakan oleh masyarakat di Desa Gubuk Klakah dan Desa Ngadas. Penelitian ini bertujuan untuk mengetahui bioprospeksi dan kelimpahan daun gatal (Laportea decumana), kemaduh (Dendrocnide stimulans (L.f) Chew) dan bedor (Girardinia palmata Gaud) oleh masyarakat desa Gubuk Klakah dan desa Ngadas. Penelitian ini dilaksanakan di Desa Gubuk Klakah dan Desa Ngadas Kecamatan Poncokusumo Kabupaten Malang pada bulan Mei- Juli 2020. Penelitian ini menggunakan metode deskriptif yang meliputi: studi pustaka, pengamatan langsung di lapangan, wawancara dengan menggunakan kuesioner, analisis data dan dokumentasi pengamatan. Responden yang diambil adalah 95 responden yang diambil dengan teknik purposive sampling. Hasil penelitian ini menunjukkan bahwa respon masyarakat desa Gubuk Klakah dan desa Ngadas tinggi mengenai pengetahuan deskripsi tumbuhan daun gatal, namun respon masyarakat di desa Ngadas tinggi mengenai pemanfaatan tentang tumbuhan bedor (Girardinia palmata Gaud) untuk keperluan adat dan pestisida alami.
\end{abstract}

Kata kunci: daun gatal, kelimpahan, Desa Gubuk Klakah, Desa Ngadas, bioprospeksi

\begin{abstract}
Stingging nettle leaves are one of the plants that are usually found by the community, but most people do not know the benefits and uses and so gatel leaves are rarely used by people in the Village of Klakah Gubuk and Desa Ngadas. This study aims to determine the bioprospection and abundance of Stingging nettle leaves Laportea decumana), kemaduh (Dendrocnide stimulant (L.f) Chew) and bedor (Girardinia palmata Gaud) by Gubuk Klakah and Ngadas villages. This research was conducted in the Village of Klakah Gubuk and Ngadas Village, Poncokusumo District, Malang Regency in May-July 2020. This research uses descriptive methods which include: literature study, field observations, interviews using questionnaires, data analysis and observation documentation. The respondents taken were 95 respondents taken purposive sampling. The results of this study indicate that the response of the community of Gubuk Klakah village and Ngadas village is high regarding the knowledge of Stingging nettle leaves plants, but the response of the community in the village of Ngadas is high regarding the utilization of the bedor (Girardinia palmata Gaud) for customary needs and natural pesticides.
\end{abstract}

Keywords: stingging nettle leaves, abundance, Gubuk Klakah Village, Ngadas Village, bioprospection

\footnotetext{
*) Ariski Vevi Liswandari, Universitas Islam Malang, Biologi FMIPA, Jl. MT. Hariyono 193, Malang 65144 Tlp. 082244411841. Email : ariski.vevi@gmail.com

**) Dr. Nour Athiroh Abdoes Sjakoer, S.Si., M.Kes Universitas Islam Malang, Biologi FMIPA, J1. MT. Hariyono 193, Malang 65144 Tlp 081330017206. Email : nour.athiroh@unisma.ac.id
}

Diterima Tanggal 1 Juni 2020 - Dipublikasikan Tanggal 25 Januari 2021 
e-Jurnal Ilmiah BIOSAINTROPIS (BIOSCIENCE-TROPIC)

Volume 6/ No.: 2 / Halaman 11 - 18 / Januari Tahun 2021

ISSN : 2460-9455 (e) - 2338-2805(p)

\section{Pendahuluan}

Kajian bioprospeksi merupakan eksplorasi biodiversitas secara sistematik untuk mengklasifikasi dan melakukan sebuah investigasi dengan tujuan untuk komersial dari senyawa kimia baru, gen, protein, mikroorganisme dan produk lainnya yang memiliki sebuah nilai ekonomi, nilai yang aktual, dan memiliki nilai potensial yang ditemukan dalam keanekaragaman hayati [1]. Perkembangan bioprospeksi semakin berkembang dari tahun ke tahun. Kajian bioprospeksi ini dapat diterapkan untuk pemanfaatan keanekaragaman hayati yang di jadikan untuk membuat obat herbal [2]. Konvensi tentang keanekaragaman hayati tentang pemanfaatan bioprospeksi harus ada pembagian secara adil antara Negara sumber keanekaragaman hayati dan didorong dengan penggunaan pada masyarakat adat maupun lokal [3]. Berdasarkan penelitian yang telah dilakukan, penelitian tentang bioprospeksi mimba pernah di lakukan di desa Bangsring [4].

Penelitian lain yang pernah dilakukan yaitu tentang daun gatal (Laportea decumana) di Papua yang memiliki potensi untuk obat anti capek [5]. Penelitian lain pada tumbuhan bedor (Girardinia palmata Gaud) telah dimanfaatkan untuk ritual jarang kepang. Penggunaannya dengan memukul tumbuhan bedor (Girardinia palamata Gaud) pada bagian pemain jarang kepang[6]. Menurut Herlina (2019) dalam penelitiannya, tumbuhan kemaduh (Dendrocnide stimulans (L.f) Chew) digunakan untuk obat batuk dan pencuci rambut [7]

Daun gatal merupakan tumbuhan perdu yang termasuk dalam famili Urticaceae. Tumbuhan daun gatal ditemukan di wilayah asia tenggara, termasuk Indonesia. Di Indonesia tumbuhan daun gatal tersebar di berbagai wilayah. Famili urticaceae di Pulau Jawa telah ditemukan 22 genus dan 76 spesies [8], sedangkan family urticaceae di Pulau Papua telah ditemukan 6 spesies yaitu: Laportea decuma, Laportea sinuarta, Dendrocnide peltata, Laportea sp, Laportea interupta dan Laportea aestuans [9]

Pemanfaatan daun gatal (Laportea decumana) dapat ditemukan di Pulau Maluku dan Papua, masyarakat menggunakan tumbuhan daun gatal (Laportea decumana) untuk obat anti nyeri, sendi, otot, memar, obat penghilang rasa sakit atau pegal, obat sakit kepala dan obat sakit perut [5]. Tumbuhan kemaduh (Dendrocnide stimulans (L.f) Chew) dapat digunakan untuk obat batuk dan sakit kepala. Pemanfaatan tumbuhan bedor (Girardinia palmata Gaud) adalah tumbuhan yang memiliki rambut atau duri timbul yang menyengat. Efek samping setelah terkena rambut atau duri tersebut dapat menimbulkan rasa sensari terbakar pada kulit, rasa gatal, kulit memerah dan melempuh. Tumbuhan bedor (Girardinia palmata Gaud) adalah tumbuhan berbahaya dan beracun, namun tumbuhan ini dapat dimanfaatkan untuk berbagai obat. Pada bagian daun dapat digunakan untuk mengatasi TBC, diabetes, obat batuk, obat demam dan rematik. Bagian akar dapat digunakan untuk obat bisul, masalah lambung obat kencing, patah tulang, sambelit dan obat luka. Pada ilmu kedokteran hewan, tumbuhan bedor (Girardinia palmata Gaud) digunakan untuk merangsang produksi susu pada hewan sapi dan kerbau. Selain itu dalam ilmu sihir, tumbuhan bedor (Girardinia palmata Gaud) digunakan untuk ritual mengusir kejahatan [10]. Pemanfaatan tumbuhan harus disertai dengan pengetahuan kelimpahan serta pelestarian pada tumbuhan.

Kelimpahan spesies adalah jumlah masing- masing individu dalam suatu tempat. Kelimpahan mempunyai arti yaitu parameter yang berbentuk kualitatif yang mencerminkan persebaran relative suatu spesies pada organisme yang masuk ke dalam suatu komunitas [11]. Kelimpahan daun gatal (Laportea decumana), kemaduh (Dendrocnide stimulans (L.f Chew) dan bedor (Girardinia palmata Gaud) ini berada pada daerah yang mempunyai ketinggian seperti halnya di daerah pegunungan. Daun gatal (Laportea decumana), kemaduh (Dendrocnide stimulans (L.f Chew) dan bedor (Girardinia palmata Gaud) mempunyai habitat yang berkarakteristik di daerah pegunungan yang memiliki kelembaban namun tumbuhan daun gatal (Laportea decumana), kemaduh (Dendrocnide stimulans (L.f Chew) dan bedor (Girardinia palmata Gaud) ini hanya dapat pada tanah kering [5].

\section{Material dan Metode}

\section{Bahan dan Alat}

Bahan yang digunakan adalah tumbuhan daun gatal (Laportea decumana), kemaduh (Dendrocnide stimulans (L.f) Chew) dan bedor (Girardinia palmata Gaud) yang berada di desa Gubuk Klakah dan Desa Ngadas sebagai bahan dalam penelitian. Alat yang digunakan dalam 
e-Jurnal Ilmiah BIOSAINTROPIS (BIOSCIENCE-TROPIC)

Volume 6/ No.: 2 / Halaman 11 - 18 / Januari Tahun 2021

ISSN : 2460-9455 (e) - 2338-2805(p)

penelitian ini meliputi: alat tulis untuk mencatat semua kegiatan, kamera untuk mendokumentasikan kegiatan, kuesioner alat yang digunakan untuk mendapatkan data respon terhadap persepsi masyarakat pada tumbuhan daun gatal (Laportea decuana), kemaduh (Dendrocnide stimulans (L.f) Chew) dan bedor (Giradinia palmata Gaud) serta buku flora untuk identifikasi dan deskripsi tumbuhan.

\section{Metode}

Metode penelitian ini menggunakan metode deskriptif. Tahapan dalam metode penelitian ini antara lain: studi pustaka, melakukan observasi, pengambilan kuesioner, analisa data serta melakukan dokumentasi. Studi pustaka bertujuan untuk refrensi peneliti. Kegiatan observasi secara langsung dilapangan dilakukan di 2 desa, yaitu: desa Gubuk Klakah dan Desa Ngadas, Kecamatan Poncokusumo. Pengambilan Kuesioner dilakukan dengan menggunakan metode purposive sampling. Responden yang diambil di desa Gubuk Klakah sebanyak 50 responden dan responden di desa Ngadas sebanyak 45 respnden. Total responden yang digunakan peneliti sebanyak 95 responden. Teknik penentuan responden dilakukan dengan menggunakan teknik purposive sampling.

Data yang digunakan oleh peneliti yaitu mengenai: pengetahuan deskripsi, pengetahuan manfaat, pennggunaan, ketertarikan bioprospeksi serta pelestarian dari daun gatal (Laportea decumana), kemaduh (Dendrocnide stimulans) dan bedor (Girardinia palmata). Peneliti menggunakan analisis data dari hasil kuesioner di desa Gubuk Klakah dan desa Ngadas yang diolah dalam Ms.excel sehingga dapat diketahui hasil dari kuesioner tersebut.

Sasaran dalam perseberan kuesioner, peneliti melakukan penyebaran kuesioner kepada tokoh masyarakat dan masyarakat umum di desa Gubuk Klakah serta desa Ngadas. Peneliti juga melakukan pengambilan gambar secara langsung yang digunakan untuk data dokumentasi dalam kegiatan penelitian dan sebagai bukti bahwa peneliti telah melakukan penelitian di desa Gubuk Klakah dan di desa Ngadas.

Langkah terakhir yaitu peneliti mengambil data kelimpahan spesies yang bertujuan untuk mengetahui jumlah pada masing- masing individu pada daerah penelitian. Peneliti menggunakan rumus

$$
\text { Kelimpahan }(\mathrm{Ind} / \mathrm{Ha})=\frac{\sum \text { individu daun gatal }}{\text { Luas total daerah pengamatan }}
$$

Penggolongan penilaian kelimpahan spesies secara kualitatif menggunakan pendekatan sebagai berikut: 1- 4000 Ind/Ha (Jarang/seldom), 4001-16000 Ind/Ha (Sesekali/once), 16001-30000 (Seringkali/often) dan $>30000$ Ind/Ha (Melimpah/plenty) [13].

\section{Hasil dan Diskusi}

Hasil kuesioner pada desa Gubuk Klakah dan desa Ngadas ditunjukkan Tabel 1. Respon Masyarakat Desa Gubuk Klakah dan Desa Ngadas Terhadap Pengetahuan Deskripsi Tumbuhan Daun Gatal (Laportea decumana), Kemaduh (Dendrocnide stimulans (L.f) Chew) dan Bedor (Girardinia palmata Gaud).

Data hasil kuesioner yang telah dijawab oleh responden desa Gubuk Klakah dan Desa Ngadas pada No. 1A, 2A dan 3A tentang pengetahuan deskripsi tumbuhan daun gatal (Laportea decumana), kemaduh (Dendrocnide stimulans (L.f) Chew) dan bedor (Girardinia palmata Gaud) dapat dilihat pada Tabel 2. diketahui bahwa pada pengetahuan deskripsi tentang tumbuhan daun gatal (Laportea decumana) di desa Gubuk Klakah dengan nilai 3.65 tinggi sedagkan pada desa Ngadas respon masyarakat tentang pengetahuan deskripsi daun gatal (Laportea decumana) sebesar 3.0, hal ini dikarenakan sebagian masyarakat telah mengathaui tumbuhan daun gatal (Laportea decumana). Pengetahuan tumbuhan kemaduh (Dendrocnide stimulans (L.f) Chew) di desa Gubuk Klakah nilai respon masyarakat sebesar 4.4 sedangkan pada desa Ngadas nilai respon masyarakat tentang pengetahuan deskripsi kemaduh (Dendrocnide stimulans (L.f) Chew) sebesar 3.71. Pengetahuan deskripsi tentang tumbuhan bedor (Girardinia palmate Gaud) di desa Gubuk Klakah sebesar 4.02 sedangkan nilai respon masyarakat di desa Ngadas sebesar 4.89, dapat disimpulkan bahwa 
e-Jurnal Ilmiah BIOSAINTROPIS (BIOSCIENCE-TROPIC)

Volume 6/ No.: 2 / Halaman 11 - 18 / Januari Tahun 2021

ISSN : 2460-9455 (e) - 2338-2805(p)

pengetahuan masyarakat mengenai pengetahuan deskripsi tumbuhan daun gatal (Laportea decumana), kemaduh (Dendrocnide stimulans (L.f) Chew) dan Bedor (Girardinia palmate Gaud) dapat dikatakan masyarakat telah mengetahui semua.

Tabel 1. Hasil Kuesioner Daun Gatal

\begin{tabular}{|c|c|c|c|c|c|}
\hline \multirow[t]{2}{*}{ No. } & \multirow[t]{2}{*}{ Jenis Pertanyaan } & \multicolumn{2}{|c|}{$\begin{array}{c}\text { Respon Masyarakat Desa } \\
\text { Gubuk Klakah }\end{array}$} & \multicolumn{2}{|c|}{$\begin{array}{c}\text { Respon Masyarakat Desa } \\
\text { Ngadas }\end{array}$} \\
\hline & & Nilai & Keterangan & Nilai & Keterangan \\
\hline $1 \mathrm{~A}$ & $\begin{array}{l}\text { Apakah Saudara mengetahui tentang } \\
\text { tumbuhan daun gatal (Laportea decumana)? }\end{array}$ & 3.65 & Tinggi & 3 & $\begin{array}{l}\text { Cukup } \\
\text { Tinggi }\end{array}$ \\
\hline $2 \mathrm{~A}$ & $\begin{array}{l}\text { Apakah Saudara mengetahui manfaat dari } \\
\text { tumbuhan daun gatal (Laportea decumana)? }\end{array}$ & 2.02 & Rendah & 2.09 & Rendah \\
\hline $3 \mathrm{~A}$ & $\begin{array}{l}\text { Apakah Saudara pernah memanfaatkan } \\
\text { tumbuhan daun gatal (Laportea decumana)? }\end{array}$ & 2.03 & Rendah & 2.02 & Rendah \\
\hline $1 \mathrm{~B}$ & $\begin{array}{l}\text { Apakah Saudara mengetahui tentang } \\
\text { tumbuhan daun gatal (Dendrocnide } \\
\text { stimulans (L.f) Chew)? }\end{array}$ & 4.30 & $\begin{array}{l}\text { Sangat } \\
\text { Tinggi }\end{array}$ & 3.71 & Tinggi \\
\hline $2 \mathrm{~B}$ & $\begin{array}{l}\text { Apakah saudara mengetahui manfaat } \\
\text { tumbuhan kemaduh (Dendrocnide stimulans } \\
\text { (L.f) Chew)? }\end{array}$ & 2.20 & Rendah & 2.27 & Rendah \\
\hline $3 \mathrm{~B}$ & $\begin{array}{l}\text { Apakah saudara pernah menggunakan } \\
\text { tumbuhan kemaduh (Dendrocnide stimulans } \\
\text { (L.f) Chew)? }\end{array}$ & 2.15 & Rendah & 2.11 & Rendah \\
\hline $1 \mathrm{C}$ & $\begin{array}{l}\text { Apakah Saudara mengetahui tentang } \\
\text { tumbuhan daun gatal (Girardinia palmata)? }\end{array}$ & 4.02 & Tinggi & 4.89 & $\begin{array}{l}\text { Sangat } \\
\text { Tinggi }\end{array}$ \\
\hline $2 \mathrm{C}$ & $\begin{array}{l}\text { Apakah saudara mengetahui manfaat } \\
\text { tumbuhan Bedor (Girardinia palmata } \\
\text { Gaud)? }\end{array}$ & 1.95 & Rendah & 4.13 & Tinggi \\
\hline $3 \mathrm{C}$ & $\begin{array}{l}\text { Apakah saudara pernah menggunakan } \\
\text { tumbuhan Bedor (Girardinia palmata } \\
\text { Gaud)? }\end{array}$ & 1.89 & Rendah & 3.58 & Tinggi \\
\hline $1 \mathrm{D}$ & $\begin{array}{l}\text { Apakah Saudara tertarik memanfaatkan } \\
\text { tumbuhan daun gatal, tumbuhan kemaduh, } \\
\text { dan Bedor untuk obat herbal? }\end{array}$ & 3.65 & Tinggi & 4.64 & $\begin{array}{l}\text { Sangat } \\
\text { Tinggi }\end{array}$ \\
\hline $2 \mathrm{D}$ & $\begin{array}{l}\text { Apakah saudara setuju jika tumbuhan } \\
\text { tumbuhan daun gatal, tumbuhan kemaduh } \\
\text { dan Bedor perlu dikenalkan untuk generasi } \\
\text { yang akan datang? }\end{array}$ & 3.59 & Tinggi & 4.6 & $\begin{array}{l}\text { Sangat } \\
\text { Tinggi }\end{array}$ \\
\hline
\end{tabular}

Tabel 2. Pengetahuan Deskripsi Daun Gatal (Laportea decumana), Kemaduh (Dendrocnide stimulans (L.f) Chew) dan Bedor (Girardinia palmata Gaud)

\begin{tabular}{lcc}
\hline \multicolumn{1}{c}{ Nama Spesies } & $\begin{array}{c}\text { Persentase Respon Desa } \\
\text { Gubuk Klakah }\end{array}$ & $\begin{array}{c}\text { Persentase Respon Desa } \\
\text { Ngadas }\end{array}$ \\
\hline Daun Gatal (Laportea decumana) & 3.65 & 3 \\
\hline $\begin{array}{l}\text { Kemaduh (Dendrocnide stimulans } \\
\text { (L.f) Chew) }\end{array}$ & 4.30 & 3.71 \\
\hline Bedor (Girardinia palmata Gaud) & 4.02 & 4.89 \\
\hline
\end{tabular}


e-Jurnal Ilmiah BIOSAINTROPIS (BIOSCIENCE-TROPIC)

Volume 6/ No.: 2 / Halaman 11 - 18 / Januari Tahun 2021

ISSN : 2460-9455 (e) - 2338-2805(p)

Hasil kuesioner yang terdapat pada soal 1B, 2B dan 3B tentang pengetahuan manfaat dari daun gatal (Laportea decumana), kemaduh (Dendrocnide stimulans (L.f) Chew) dan bedor (Girardinia palmata Gaud) di desa Gubuk Klakah dan desa Ngadas dapat dilihat pada Tabel 3.

Tabel 3. Pengetahuan manfaat Daun Gatal (Laportea decumana), Kemaduh (Dendrocnide stimulans (L.f) Chew) dan Bedor (Girardinia palmata Gaud)

\begin{tabular}{lcc}
\hline \multicolumn{1}{c}{ Nama Spesies } & $\begin{array}{c}\text { Persentase Respon Desa } \\
\text { Gubuk Klakah }\end{array}$ & $\begin{array}{c}\text { Persentase Respon Desa } \\
\text { Ngadas }\end{array}$ \\
\hline Daun Gatal (Laportea decumana) & 2.02 & 2.09 \\
\hline $\begin{array}{l}\text { Kemaduh (Dendrocnide stimulans } \\
\text { (L.f) Chew) }\end{array}$ & 2.20 & 2.27 \\
\hline Bedor (Girardinia palmata Gaud) & 1.95 & 4.13 \\
\hline
\end{tabular}

Hasil dari pengetahuan masyarakat di desa Gubuk Klakah dan desa Ngadas tentang pengetahuan manfaat daun gatal (Laportea decumana), kemaduh (Dendrocnide stimulans (L.f) Chew) dan bedor (Girardinia palmata Gaud). Diketahui hasil pada tabel 3 tersebut, pengatahuan tentang manfaat daun gatal (Laportea decumana) pada desa Gubuk Klakah dengan nilai 2.02, sedangkan pada desa Ngadas respon masyarakat dengan nilai 2.09. Hal ini dikarenakan masyarakat tidak mengetahui manfaat dari daun gatal (Laportea decumana). Respon masyarakat tentang pengetahuan manfaat pada kemaduh (Dendrocnide stimulans (L.f) Chew) di desa Gubuk Klakah dengan nilai 2.20 dan desa Ngadas respon masyarakat tentang pengetahuan manfaat kemaduh (Dendrocnide stimulans (L.f) Chew) yaitu: 2.27. Sedangkan respon masyarakat mengenai pengetahuan manfaat tentang bedor (Girardnia palmata Gaud) di desa Gubuk Klakah dengan nilai 1.95 dan respon masyarakat pada desa Ngadas tentang pengetahuan manfaat di desa Ngadas dengan nilai 4.13. Tingginya tingkat pengetahuan pada desa Ngadas dikarenakan masyarakat Ngadas mengetahui menggunakan tumbuhan bedor (Girardinia palmata Gaud) untuk keperluan ritual adat, namun yang dapat menggunakannya hanya sesepuh dan dukun.

Hasil kuesioner di nomer 1C, 2C dan 3C tentang pemanfaatan dan penggunaan tentang daun gatal (Laportea decumana), kemaduh (Dendrocnide stimulans (L.f) Chew) dan bedor (Girardinia palmata Gaud) di desa Gubuk Klakah dan desa Ngadas dapat dilihat pada Tabel 3.

Tabel 4. Penggunaan Daun Gatal (Laportea decumana), Kemaduh (Dendrocnide stimulans (L.f) Chew) dan Bedor (Girardinia palmata Gaud)

\begin{tabular}{lcc}
\hline \multicolumn{1}{c}{ Nama Spesies } & $\begin{array}{c}\text { Persentase Respon Desa } \\
\text { Gubuk Klakah }\end{array}$ & $\begin{array}{c}\text { Persentase Respon Desa } \\
\text { Ngadas }\end{array}$ \\
\hline Daun Gatal (Laportea decumna) & 2.03 & 2.02 \\
\hline $\begin{array}{l}\text { Kemaduh (Dendrocnide stimulans } \\
\text { (L.f) Chew) }\end{array}$ & 2.15 & 2.11 \\
\hline Bedor (Girardinia palmata Gaud) & 1.89 & 4.58 \\
\hline
\end{tabular}

Pada Tabel 4 dapat dilihat penggunaan daun gatal (Laportea decumana) di desa Gubuk Klakah respon masyarakat yaitu: 2.03 sedangkan respon masyarakat di desa Ngadas sebesar 2.02. Respon masyarakat tentang penggunaan kemaduh (Dendrocnide stimulans (L.f) Chew) di desa Gubuk Klakah 
e-Jurnal Ilmiah BIOSAINTROPIS (BIOSCIENCE-TROPIC)

Volume 6/ No.: 2 / Halaman 11 - 18 / Januari Tahun 2021

ISSN : 2460-9455 (e) - 2338-2805(p)

sebesar 2.15, sedangkan respon masyarakat di desa Ngadas sebensar 2.11. Pengguanaan bedor (Girardinia palmata Gaud) pada desa Gubuk Klakah, respon masyarakat yaitu: 1.89 sedangkan respon masyarakat di desa Ngadas tentang penggunaan tumbuhan bedor (Girardinia palmata Gaud) yaitu: 4.58. Nilai rendah pada penggunaan daun gatal (Laportea decumana) di desa Gubuk Klakah dan desa Ngadas, kemaduh (Dendrocnide stimulans (L.f) Chew di desa Gubuk Klakah dan desa Ngadas, dan penggunaan tumbuhan bedor (Girardinia palmata Gaud) di desa Gubuk Klakah rendah karena masyarakat kurang mengetahui tentang manfaat, sehingga masih belum banyak masyarakat sekitar yang menggunakannya. Tingginya nilai persentase pengguanaan tumbuhan bedor (Girardinia palmata Gaud) di desa Ngadas dikarena sebagian masyarakat menggunakan tumbuhan bedor (Girardinia palmate Gaud) untuk ritual adat dan pestisida alami pemberantas hama tikus. Menurut Quattrocchi, (2019), dalam ilmu sihir tumbuhan bedor (Girardinia palmata Gaud) digunakan untuk mengusir kejahatan [10].

Hasil kuesioner tentang pengetahuan manfaat dari daun gatal (Laportea decumana), kemaduh (Dendrocnide stimulans (L.f) Chew) dan bedor (Girardinia palmata Gaud) di desa Gubuk Klakah dan desa Ngadas dapat dilihat pada Tabel 5.

Tabel 5. Respon Masyarakat Terhadap Ketertarikan Bioprospeksi dan Pelaksanaan Tumbuhan Daun Gatal di Desa Gubuk Klakah dan Desa Ngadas

\begin{tabular}{|l|c|c|c|c|}
\hline \multirow{2}{*}{ Nama Spesies } & \multicolumn{2}{|c|}{ Desa Gubuk Klakah } & \multicolumn{2}{c|}{ Desa Ngadas } \\
\cline { 2 - 5 } & Bioprospeksi & Pelestarian & Bioprospeksi & Pelestarian \\
\hline $\begin{array}{l}\text { Daun gatal (Laportea } \\
\text { decumana), Kemaduh } \\
\text { (Dendrocnide stimulans } \\
\begin{array}{l}\text { (L.f) Chew) dan Bedor } \\
\text { (Girardinia palmata Gaud) }\end{array}\end{array}$ & 3.65 & 3.59 & 4.64 & 4.6 \\
\hline
\end{tabular}

Pada tabel 5. adalah hasil dari respon masyarakat mengenai bioprospeksi dan pelestarian daun gatal (Laportea decumana), kemaduh (Dendrocnide stimulans (L.f) dan bedor (Girardinia palmata Gaud) pada tabel 4 dapat diketahui bahwa respon masyarakat terhadap ketertarikan bioprospeksi dan pelestarian daun gatal pada desa Gubuk Klalah yaitu: 3.65 dan untuk pelestarian tumbuhan daun gatal 3.59, sedangkan respon masyarakat di desa Gubuk Klakah dan desa Ngadas pada ketertarikan pada bioprospeksi dengan nilai 4.64 dan pelestarian terhadap tumbuhan daun gatal yaitu dengan nilai 4.6.

Tabel 6. Hasil Kelimpahan Spesies Daun Gatal di Desa Gubuk Klakah dan Desa Ngadas

\begin{tabular}{|l|c|c|c|c|c|c|}
\hline \multicolumn{1}{|c|}{ Kelimpahan } & Plot 1 & Plot 2 & Plot 3 & Plot 4 & Plot 5 & Keterangan \\
\hline $\begin{array}{l}\text { Daun Gatal } \\
\text { (Laportea } \\
\text { decumana) }\end{array}$ & 0 & 0 & 0 & 0 & 14,28 & Jarang \\
\hline $\begin{array}{l}\text { Kemaduh } \\
\text { (Dendrocnide } \\
\text { stimulans } \\
\text { (L.F) Chew) }\end{array}$ & 86,67 & 73,33 & 0 & 0 & 0 & Jarang \\
\hline $\begin{array}{l}\text { Bedor } \\
\text { (Girardinia } \\
\text { palmata } \\
\text { Gaud) }\end{array}$ & 0 & 0 & 357,14 & 185,71 & 0 & Jarang \\
\hline
\end{tabular}


Hasil dari Tabel 6 dapat diketahu bahwa kelimpahan spesies pada setiap plot tidak merata. Hal ini dikarenakan pada setiap wilayah pengamatan tidak ditemukan tumbuhan tersebut, sehingga memunculkan nilai 0 pada sebagian plot. Hasil kelimpahan pada tumbuhan daun gatal (Laportea decumana) dapat diketahui pada plot 5 dengan jumlah individu yaitu 14,28 Ind/Ha, tumbuhan kemaduh (Dendrocnide stimulans (L.f) Chew) hanya terdapat pada plot 1 dan plot 2 dengan nilai 86,67 Ind/Ha dan 73,33 Ind/Ha dan kelimpahan spesies bedor (Girardinia palmata Gaud) dapat diketahui di plot 3 dan 4 dengan nilai individu yaitu: 357,14 Ind/Ha dan 185,71 Ind/Ha.

\section{Kesimpulan}

Sebagian besar pada desa Gubuk Klakah telah mengetahui tumbuhan kemaduh (Dendrocnide stimulans (L.f) Chew) dan bedor (Girardinia palmata Gaud), namun untuk pengetahuan akan tumbuhan daun gatal (Laportea decumana) masyarakat masih belum mengetahui. Pengetahuan tentang manfaat dari ketiga daun gatal tersebut, di desa gubuk klakah tidak mengetahui manfaatnya, sehingga sebagian besar masyarakat tidak menggunakan tumbuhan tersebut. Pada desa Ngadas pengetahuan pemanfaatan tumbuhan daun gatal hanya pada tumbuhan bedor (Girardinia palmata Gaud), masyarakat di desa Ngadas menggunakan tumbuhan bedor (Girardinia palmata) untuk ritual adat dan untuk pestisida alami pada kedua desa ketertarikan tentang bioprospeksi dan pelestarian tumbuhan daun gatal (Laportea decumana), kemaduh (Dendrocnide stimulans (L.f) Chew) dan bedor (Girardinia palmate Gaud) respon masyarakat sangat tinggi dan kelimpahan spesies pada spesies daun gatal (Laportea decumana), kemaduh (Dendrocnide stimulans (L.f) Chew) dan bedor (Girardinia palmate Gaud) pada desa Gubuk Klakah dan Desa Ngadas dikategorikan jarang, karena jumlah individu kurang dari $4000 \mathrm{Ind} / \mathrm{Ha}$.

\section{Daftar Pustaka}

[1] Reid, W.V., Laird, S.A., Meyer, C.A., Gomez, R., Sittenfeld, A., Janzen, D.H., Gollin, M.A. and Juma, C. (Eds.). 1993. Biodiversity Prospecting: Using Genetic Resources for Sustainable Development. World Resources Institute, Wa Shing ton, DC; Instituto Nacional de Biodiversidad, Santo Domingo de Heredia, Costa Rica; Rainforest Alliance, New York. African Centre for Technology Studies, Nairobi, Kenya.

[2] Pusat Inovasi LIPI. 2004. Bioprospeksi dan Pembagian Manfaat (Benefit Sharing) Melalui Kerjasama Penelitian. Makalah Disampaikan dalam Sosialisasi dan Curah Pendapat Mengenai Kebijakan HKI dalam Kerjasama Penelitian Asing di Indonesia, 4 Agustus 2004, Samarinda. Pusat Inovasi LIPI dan Balai Penelitian dan Pengembangan Kehutanan Kalimantan. Samarinda.

[3] Svarstad, H. 2006. Bioprospecting: Global discourses and local perceptions- Shaman Pharmaceuticals in Tanzania. Doctoral Thesis. University of Oslo.

[4] Baidarus, A. 2019. Bioprospeksi Mimba (Azadirachta indica Juss.) Sebagai Tumbuhan Obat di Desa Bangsring Kecamatan Wongsorejo Kabupaten Banyuwangi. Jurnal Sains Alami. Universitas Islam Malang

[5] Simaremare, E.S., Ruban, A., Nainggolan, M., Yenusi, C., Wabiser, G., dan Gunawan, E. 2014. Pemanfaatan Daun Gatal (Laportea decumana (Roxb.) Wedd) Varietas Biak Sebagai Anti Nyeri. Proseing Seminar Nasional Biologi, 5(1). Hal: 190-195.

[6] Oktavia, A.I. 2017. Etnobotani Tumbuhan Beracun di Desa Ngadiwono Kecamatan Tosari Kabupaten Pasuruan. Tesis. Universitas Brawijaya.

[7] Herlina, N. 2019. Inventarisasi Jenis Tumbuhan Berkhasiat Obat di Zora Rehabilitasi Blok Pasir Batang Taman Nasional Gunung Ciremai. Prosiding Seminar Nasional dan Call for Papers. Universitas Soederman. Purwokerto. 
e-Jurnal Ilmiah BIOSAINTROPIS (BIOSCIENCE-TROPIC)

Volume 6/ No.: 2 / Halaman 11 - 18 / Januari Tahun 2021

ISSN : 2460-9455 (e) - 2338-2805(p)

[8] Backer, C.A., and Bakhuizen van den Brink Jr., R. C. 1965. Flora of Java. Vol. 2. N. V. P. Noordhoff. Groningen.

[9] Mom, S.A, Langi, M.A., Kainde, R.P., dan Nurwawan, W. 2016. Studi Etnobotani Daun Gatal di Kecamatan Kwamkilama Kabupaten Mimika. Ilmu Kehutanan. Universitas Samratulangi. Manado

[10] Quattrocchi, U. 2019. CRC World Dictionary of Medicinal and Poisonous Plant (Common Names, Scientific Names, Eponyms, Synonyms and Etymology). CRC Press. Harvard University and Harvard University Herbaria, Cambridge, Massachusetts.

[11] Indrayanto. 2006. Ekologi Hutan. Bumi Aksara. Jakarta

[12] [WHO] World Health Organization. 2009. Medicinal plants in Papua New Guinea. World Health Organization, regional office for the Western Pacific. Manila.

[13] Pujianingsih, R.I.2005. Identification of Natural Feed of Anoa (Bubalus spp.) in Advance of Wildlife Concervatation. Proceedings of The XXVII Congress of The International Union of Game Biologist. Hannover Germany. 31 Agustus 2005. 